\title{
FORMAL AND PROFESSIONAL REOUIREMENTS FOR THE STAFF OF HYPERBARIC CENTRES. Part 1
}

\author{
WYMOGI FORMALNE I FACHOWE STAWIANE PERSONELOWI OŚRODIKÓW \\ hIPERBarYCZNYCh. CZĖŚĆ 1
}

\author{
ФОРМАЛЬНЫЕ И ПРОФЕССИОНАЛЬНЫЕ ТРЕБОВАНИЯ К ПЕРСОНАЛУ \\ ГИПЕРБАРИЧЕСКИХ БАРОКАМЕР. ЧАСТЬ 1
}

\section{Formelle und fachliche finforderungen an das Personal von ÜBerdruckKammern. TEIL 1}

\section{REQUISITOS FORMALES Y PROFESIONALES REQUERIDOS AL PERSONAL DE CÁMARAS hIPERBáRICAS. Parte 1}

\author{
Piotr Siermontowski ${ }^{1)}$, Beata Janas ${ }^{3)}$, Romuald Olszański ${ }^{2)}$ \\ 1) Polish Naval Academy, Department of Underwater Works Technology, Gdynia, Poland \\ ${ }^{1)}$ Akademia Marynarki Wojennej, Zakład Technologii Prac Podwodnych w Gdyni \\ 2) Institute of Maritime and Hyperbaric Medicine of the Military Medical Institute, Gdynia, Poland \\ ${ }^{2)}$ Zakład Medycyny Morskiej i Hiperbarycznej Wojskowego Instytutu Medycznego \\ ${ }^{3)}$ Cancer Prevention Centre, Oncology Centre, Warsaw, Poland \\ 3) Centrum Profilaktyki Nowotworów Centrum Onkologii Warszawa
}

\section{StRESZCZENIA / ABSTRACTS}

This two-part article reviews the current legal situation of specialist staff performing hyperbaric procedures for purposes not related to diving. Numerous discrepancies between the applicable legal acts and the lack of legal regulations concerning procedures not financed from the state budget have been noted.

The first significant problem consisted in the lack of a correlation between various Regulations of the Minister of Health concerning hyperbaric oxygenation, as well as inconsistencies with the programmes of medical specialisation effective in Poland.

The second problem is the lack of determination requirements of medical personnel other than doctors and nurses in the documents of the Ministry of Health.

It was also found that medical hyperbaric centres which do not apply for funding from the budget (National Health Fund), do not even meet the minimum requirements defined as to the qualifications of the staff working there. Moreover, there is a lack of knowledge of the requirements set out in legal acts other than those concerning medicine.

Keywords: hyperbaric treatment, personnel, specialisation, qualifications

W dwuczęściowym artykule dokonano przeglądu aktualnej sytuacji prawnej personelu fachowego wykonującego procedury hiperbaryczne inne, niż nurkowe. Wykazano liczne sprzeczności pomiędzy obowiązującymi aktami prawnymi i brak regulacji prawnych dotyczących procedur nie finansowanych z budżetu Państwa.

Pierwszym istotnym problemem był brak korelacji różnych, dotyczących hiperbarii Rozporządzeń Ministra Zdrowia a także niespójności z obowiązującymi w Polsce programami specjalizacji lekarskich

Drugi problem to brak określenia w dokumentach Ministerstwa Zdrowia wymagań w stosunku do innego niż lekarze i pielęgniarki personelu medycznego. Stwierdzono także, że medyczne ośrodki hiperbaryczne nie ubiegające się o finansowanie z budżetu (NFZ) nie mają określonych nawet minimalnych wymagań co do kwalifikacji pracującego w nich personelu. Brak jest także znajomości wymagań określonych w innych niż dotyczące medycyny aktach prawnych.

Słowa kluczowe: leczenie hiperbaryczne, personel, specjalizacja, kwalifikacje.

ARTICLE INFO

PolHypRes 2017 Vol. 61 Issue 4 pp. 7 - 14

ISSN: $1734-7009$ elSSN: $2084-0535$

DOI: $10.1515 / \mathrm{phr}-2017-0017$

Pages: 13 , figures: 1 , tables: 0

page www of the periodical: www.phr.net.pl

Publisher

Polish Hyperbaric Medicine and Technology Society
Typ artykułu: przeglądowy

Review article

Termin nadesłania: $13.11 .2017 \mathrm{r}$.

Termin zatwierdzenia do druku: 10.12.2017r. 
В статье, состоящей из двух частей, приведен обзор актуальной правовой ситуации профессионального персонала, выполняющего гипербарические процедуры иные, чем ныряние. Перечислен ряд противоречий между действующими правовыми нормами и отсутствием правового урегулирования, касающегося процедур, которые не финансируются из государственного бюджета.

Первой существенной проблемой было отсутствие корреляции различных, касающихся гипербарии, распоряжений министра здравоохранения, а также несогласованности с действующими в Польше программами врачебной специализации.

Вторая проблема - это отсутствие в документах министерства здравоохранения требований к остальному медицинскому персоналу, исключая врачей и медсестер.

Выявлено также, что медицинские гипербарические центры, не подающие заявку на финансирование из государственного бюджета (НФ3), не имеют сформулированных даже минимальных требований к квалификации работающего у них персонала. Также отсутствует знание требований, определенных в иных, чем касающихся медицины, правовых актах

Ключевые слова: гипербарическое лечение, персонал, специализация, квалификация.

Im zweiteiligen Artikel wird eine Übersicht über die aktuelle rechtliche Lage von Fachpersonal gegeben, das andere hyperbare Prozeduren als Tauchprozeduren ausführt. Es wurden zahlreiche Widersprüche zwischen den geltenden Rechtsakten und dem Fehlen rechtlicher Regulierung von Prozeduren aufgezeigt, die nicht aus der Staatskasse finanziert werden.

Das erste wesentliche Problem war das Fehlen unterschiedlicher Korrelationen bezüglich der Hyperbarie der Verordnungen des Gesundheitsministeriums aber auch Inkonsistenzen in Bezug auf die in Polen geltenden Programme für die Facharztausbildung.

Das zweite Problem ist, dass in den Dokumenten des Gesundheitsministeriums die Anforderungen an anderes medizinisches Personal als Ärzte und Krankenschwestern fehlen.

Es wurde außerdem festgestellt, das medizinische hyperbare Einrichtungen, die keine Finanzierung aus dem Budget der nationalen Krankenkasse NFZ beantragen, nicht einmal Minimalanforderungen an die Qualifikationen des bei innen arbeitenden Personals festgelegt haben. Es fehlen auch Kenntnisse über die Anforderungen, die in anderen, nicht die Medizin betreffenden, Rechtsakten festgelegt sind.

Schlüsselwörter: hyperbare behandlung, personal, spezialisierung, qualifikationen.

Este artículo de dos partes establece una revisión de la situación legal actual del personal profesional que realiza procedimientos hiperbáricos distintos al submarinismo. Se han puesto de relieve numerosas contradicciones entre la legislación vigente y la falta de regulación relativa a los procedimientos no financiados mediante fondos públicos.

El primer problema importante ha sido la falta de correlación existente entre los distintos reglamentos del Ministro de Salud referidos a la hiperbaria, as como inconsistencias presentes en los distintos programas actuales de especialización médica en Polonia.

El segundo problema es que la documentación del Ministerio de Salud no especifica los requisitos necesarios para el personal médico distinto a médicos y enfermeros.

También se ha constatado que los centros médicos hiperbáricos que no solicitan financiación pública (NFZ) ni siquiera cuentan con unos requisitos mínimos de cualificación para el personal que trabaja en ellos. También existe un desconocimiento de los requisitos establecidos en la legislación distintos a los médicos.

Palabras clave: tratamiento hiperbárico, personal, especialización, cualificaciones. 


\section{WSTĘP}

W związku z intensywnym rozwojem ośrodków terapii hiperbarią tlenową, zarówno finansowanych przez Państwo za pośrednictwem Narodowego Funduszu Zdrowia, jak i prywatnych, uznaliśmy za wskazaną analizę wymogów formalnych stawianych pracującemu tam personelowi fachowemu, zarówno medycznemu jak i technicznemu.

Personel fachowy ośrodka hiperbarycznego to:

- Lekarz

- Pielęgniarka;

- tzw. „attendent”, asystent komorowy;

- Operator komory.

W pierwszej części artykułu zajęto się wymaganiami w stosunku do lekarzy.

Terapia tlenem hiperbarycznym stosowana jest w coraz to liczniejszych chorobach, którymi zajmują się lekarze różnych specjalności. Konsensus co do przyjętych w Europie wskazań do leczenia hiperbarycznego podjęto na 7th European Consensus Conference on Hyperbaric Medicine w Lille we Francji w 2004 roku. Wskazania te opisane zostały $\mathrm{w}$ polskim podręczniku medycyny hiperbarycznej, pod redakcją profesorów Aleksandra Sieronia i Grzegorza Cieślara [1] ze Śląskiego Uniwersytetu Medycznego. Podręcznik ten uwzględnił postęp, jaki nastąpił w tej dziedzinie medycyny, od czasu wydania poprzedniego polskiego podręcznika autorstwa profesorów Tadeusza Doboszyńskiego i Tadeusza Orłowskiego [2] z Wojskowej Akademii Medycznej wydanego w 1977 roku.

Znacznie szerszy zakres wskazań terapeutycznych obowiązuje za oceanem [3,4], gdzie w USA określa go American Committee of Hyperbaric Medicine (ACHM).

W największym skrócie, zatwierdzone w Lille europejskie wskazania to terapii hiperbarycznej możemy podzielić na: toksykologiczne (zatrucie CO), nurkowe (choroba dekompresyjna, uraz ciśnieniowy płuc), laryngologiczne (ostra utrata słuchu), chirurgiczne (zespół zmiażdżenia, rany przewlekłe, oparzenia), chirurgia $\mathrm{z}$ diabetologią (stopa cukrzycowa), ortopedyczne (zakażenia kości i szpiku, złamania kości), zakaźne (zakażenia, szczególnie beztlenowcami), hematologiczne (znacznego stopnia niedokrwistość) $[1,2]$. Oczywiście tlen hiperbaryczny stosowany jest także w wielu innych zespołach chorobowych, dla których określono wskazania do leczenia (np. zespół stresu pourazowego) jak i bez tych wskazań (np. mózgowe porażenie dziecięce).

Logicznym więc wydawało by się, aby poszczególne specjalności lekarskie poszerzyły zakres stosowanych procedur terapeutycznych o terapię hiperbarią tlenową, co znalazło by swoje odzwierciedlenie w programach specjalizacji.

Drugą możliwością byłoby włączenie terapii hiperbarycznej jako całości $\mathrm{w}$ ramy jednej specjalizacji i „wykonywanie usług” pod postacią procedur leczenia hiperbarycznego dla innych specjalności medycznych.

Analizując szczegółowo programy specjalizacji medycznych, zarówno jednostopniowe, jak i obecne modułowe, autorzy doszli do wniosku, że ich twórcy poszli raczej tą drugą drogą.

W niektórych programach specjalizacyjnych znajdujemy wzmianki o zastosowaniu terapii

\section{INTRODUCTION}

Due to the intense development of hyperbaric oxygen therapy centres financed both by the State, from the National Health Fund, and from private funds, we found it purposeful to analyse the formal requirements for professional personnel, both medical and technical, working at such facilities. consists of:

The professional staff of a hyperbaric centre

- Doctor;

- Nurse;

- the "Attendant", (often referred to as the chamber assistant);

- Chamber operator.

The first part of the article deals with the requirements for doctors.

Hyperbaric oxygen therapy is applied in relation to an ever-expanding number of diseases by doctors of various specialisations. The consensus on the indications for hyperbaric treatment adopted in Europe was reached at the 7th European Consensus Conference on Hyperbaric Medicine in Lille, France, in 2004. The indications are described in the Polish textbook on hyperbaric medicine edited by professors Aleksander Sieroń and Grzegorz Cieślar [1] from the Medical University of Silesia. The textbook took into account the progress that has been made in this field of medicine since the publication of the previous Polish textbook by professors Tadeusz Doboszyński and Tadeusz Orłowski [2] from the Military Medical Academy issued in 1977.

A much wider range of therapeutic indications is approved in the USA $[3,4]$ where it is defined by the American Committee of Hyperbaric Medicine (ACHM).

In brief, the indications for hyperbaric therapy approved in Lille can be divided into: toxicological (CO poisoning), diving (decompression sickness, pulmonary barotrauma), ENT (acute hearing loss), surgical (crush syndrome, chronic wounds, burns) surgery with diabetology (diabetic foot), orthopaedic (bone and bone marrow infections, bone fractures), infectious (infections, especially with anaerobes), haematological (significant anaemia) [1,2]. Of course, hyperbaric oxygen is also used in many other diseases for which it is indicated (e.g. posttraumatic stress disorder) or even where there are no such indications (e.g. cerebral palsy).

Therefore, it seems logical that particular medical specialisations should extend the scope of therapeutic procedures utilising hyperbaric oxygen therapy, which would then be reflected in the specialisation programmes.

The second possibility would be to include hyperbaric therapy as a whole within the framework of one specialisation and "performed services" in the form of hyperbaric treatment procedures for other medical specialisations.

When analysing in detail the programmes of medical specialisations, both single-stage and the present - modular, the authors concluded that their creators followed the latter route.

In some specialisation programmes we find references to the application of hyperbaric therapy, for instance Clinical Toxicology - modular specialisation [5] where in the specialised module, in the chapter dealing with treatment of patients who have been poisoned, we 
hiperbarycznej, jak np. Toksykologia Kliniczna specjalizacja modułowa [5], gdzie w module specjalistycznym, w rozdziale dotyczącym postępowania leczniczego w zatruciach znajdujemy punkt e) wskazania do terapii normo- $i$ hiperbarycznej a $\mathrm{w}$ wykazie umiejętności praktycznych punkt 13. Zastosowania tlenoterapii hiperbarycznej $w$ toksykologii klinicznej. W poprzedniej wersji programu, gdy Toksykologia Kliniczna występowała jako specjalizacja szczegółowa, wzmianek dotyczących leczenia hiperbarycznego nie było [6].

Podobnie jest ze specjalizacjami z Ortopedii i Traumatologii, oraz Chorób Zakaźnych, gdzie w programie jednostopniowym o hiperbarii nie było wzmianki [7], natomiast w specjalizacji obecnej, modułowej w kursie „Ratownictwo medyczne”, w dziale „Zaawansowana resuscytacja krążeniowo - oddechowa” jeden z tematów brzmi: ... wentylacja zastępcza, protekcja centralnego układu nerwowego, hipotermia terapeutyczna, terapia nerkozastępcza, tlenoterapia hiperbaryczna [6].

W innych specjalnościach, w których terapia hiperbaryczna znajduje obecnie zastosowanie, w programach specjalizacji, zarówno modułowym, jak i poprzednim, jednostopniowym wzmianek o leczeniu tlenem pod zwiększonym ciśnieniem nie znajdujemy $[5,6,7]$. Przykładami są tu chirurgia (ogólna i naczyniowa), diabetologia, hematologia czy otolaryngologia.

Znacznie szerszy zakres wiedzy z zakresu leczenia hiperbarycznego znajdujemy w programach specjalizacji z zakresu Medycyny Transportu [7], Medycyny Lotniczej i przede wszystkim, Medycyny Morskiej i Tropikalnej [5].

W nieistniejącej obecnie specjalizacji jednostopniowej Medycyna Transportu znajdujemy kurs medycyny lotniczej a w nim punkt: nagła dekompresja i choroba dekompresyjna, a także kurs medycyny morskiej z tematem: opieka lekarska przy pracach podwodnych, patologia i klinika choroby dekompresyjnej. Podczas stażu kierunkowego z zakresu medycyny morskiej: udział $w$ co najmniej 10 procedurach terapii hiperbarycznej.

Medycyna Lotnicza w module specjalistycznym zawiera szerszy zakres wiedzy na temat hiperbarii, zarówno praktycznej: Szkolenie umiejętności wykonywania zabiegów i procedur medycznych punkt 3. Ekspozycja na nagła dekompresje - udziat w 20 procedurach pod nadzorem specjalisty, jak i teoretycznych: kurs wprowadzający punkt 24) Choroba ciśnieniowa, nagła dekompresja.

Medycyna Morska i Tropikalna: cytując za celem szkolenia specjalizacyjnego modułu specjalistycznego: Obszar specjalizacji obejmuje potrzeby zdrowotne ... osób poddanych hiperbarii. Jako uzyskane kompetencje zawodowe wymieniane są: punkt 1 . C. wykonywaniem pracy $w$ warunkach podwyższonego ciśnienia otoczenia. W punkcie 2) oceniać rodzaje ryzyka ... narażenia na podwyższone ciśnienie otoczenia. Program specjalizacji zawiera tygodniowy kurs „Medycyna hiperbaryczna i nurkowa”, oraz staż kierunkowy w zakresie medycyny hiperbarycznej i nurkowej obejmujący między innymi uczestnictwo w 10 procedurach leczenia hiperbarycznego.

Najistotniejsze zapisy brzmią: w zakresie wymaganej wiedzy - Oczekuje się, że lekarz po ukończeniu szkolenia specjalizacyjnego $w$ dziedzinie medycyny morskiej i tropikalnej wykaże sie przedstawiona poniżej wiedza: .... 3) Medycyna nurkowa i hiperbaryczna - wpływ podwyższonego ciśnienia na ustrój człowieka, wypadki find the following points e) indications for normo- and hyperbaric therapy and in the list of practical skills point 13. The application of hyperbaric oxygen therapy in clinical toxicology. In the previous version of the programme, where Clinical Toxicology appeared as a detailed specialisation, there were no mentions of hyperbaric treatment [6].

The same applies to the specialisations under Orthopaedics and Traumatology, and Infectious Diseases, where there was no mention [7] of hyperbaric oxygenation in the single-stage programmes, however in the current modular specialisation of the course "Emergency medical services" in the section "Advanced cardiopulmonary resuscitation" one of the subjects is: ... substitute ventilation, central nervous system protection, therapeutic hypothermia, renal replacement therapy, hyperbaric oxygen therapy. [6].

In other specialisations where hyperbaric therapy is currently applied, we do not find mentions on treatment with the use of oxygen under increased pressure in either the modular or the previous singlestage specialisation programmes [5,6,7]. Examples are surgery (general and vascular), diabetology, haematology, or otolaryngology.

A much wider scope of knowledge in the field of hyperbaric treatment is found in the specialisation programmes of Transport Medicine [7], Aviation Medicine and, above all, Maritime and Tropical Medicine [5].

In the no longer existent one-stage specialisation of "Transport Medicine", we find a course in aviation medicine and the section sudden decompression and decompression sickness as well as a course in marine medicine with the subject of medical care in underwater works, pathology and clinic of decompression sickness. During the internship in the field of marine medicine, we find an entry on participation in at least 10 hyperbaric therapy procedures.

The specialised Aviation Medicine module, contains a wider scope of knowledge on hyperbaric therapy, in the practical: Training in the performance of medical procedures - point 3. Exposure to sudden decompression - participation in 20 procedures under the supervision of a specialist, and in the theoretical: introductory course - point 24) Decompression sickness, sudden decompression.

Maritime and Tropical Medicine: citing the objective of the specialisation training in the specialisation module: The area of specialisation includes health needs ... of individuals subjected to hyperbaric therapy. The list of acquired professional competences contains: point 1 . C. work performance in the conditions of elevated ambient pressure. Point 2) risk type assessment ... in the exposure to elevated ambient pressure. The specialisation programmes include a weekly course "Hyperbaric and diving medicine", as well as an internship in the field of hyperbaric and diving medicine, including participation in 10 hyperbaric treatment procedures.

The most important provisions are: within the required knowledge - $A$ physician is expected to demonstrate the following knowledge upon completion of the specialisation training in the field of marine and tropical medicine: .... 3) Diving and hyperbaric medicine the effect of elevated pressure on the human body, decompression accidents, pressure injuries, other diving diseases, decompression principles, prevention of diving diseases, ... the use of elevated oxygen pressure in the 
dekompresyjne, urazy ciśnieniowe, inne choroby nurkowe, zasady dekompresji, profilaktyka chorób nurkowych, ... zastosowanie podwyższonego ciśnienia tlenu $w$ terapii chorób $z$ innych dziedzin medycyny ... $\quad$ w zakresie umiejętności praktycznych - 11)_znajomości zasad prowadzenia terapii hiperbarycznej dla innych specjalności medycznych.

$\mathrm{Na}$ podstawie programu szkolenia specjalizacyjnego tę właśnie specjalność medyczną należy uznać za posiadającą wszelkie predyspozycje do prowadzenia leczenia hiperbarycznego.

Na szczególną uwagę zasługuje też specjalizacja $\mathrm{z}$ zakresu Anestezjologii. 0 ile $\mathrm{w}$ poprzednio obowiązującym programie specjalizacji jednostopniowej $\mathrm{w}$ rozdziale poświęconym intensywnej terapii dział "Toksykologia" znajdujemy podpunkt 4. Terapia hiperbaryczna [7], to już w obecnie obowiązującym programie specjalizacji Anestezjologia i Intensywna Terapia (modułowa) brak jest jakiejkolwiek wzmianki o leczeniu hiperbarycznym. Zapewne kierujący Zespołem Ekspertów tworzących program specjalizacji, Pan Profesor Krzysztof Kusza doszedł do słusznego wniosku, że terapia hiperbaryczna nie ma zastosowania ani $\mathrm{w}$ znieczuleniach, ani $\mathrm{w}$ intensywnej terapii, więc zagadnienia te w programie się nie znalazły [5].

Ponieważ jednak specjalistów z zakresu Medycyny Morskiej i Tropikalnej, podobnie jak Medycyny Transportu czy Medycyny Lotniczej jest w Polsce bardzo niewielu, najlepszym rozwiązaniem problemu kwalifikacji byłaby Umiejętność Medyczna. Pozwoliłaby ona specjalistom z dziedzin, w których terapia hiperbaryczna ma zastosowanie; np. chirurgom czy otolaryngologom na zdobycie wiedzy potrzebnej do bezpiecznego posługiwania się tą metodą terapii. I faktycznie, umiejętność taka znajduje się na liście „umiejętności z zakresu węższych dziedzin medycyny” [8].

Załącznik 1 do tego rozporządzenia stanowi wykaz umiejętności, gdzie pod pozycją 30 znajduje się Medycyna Hiperbaryczna. Załącznik 2 określa natomiast dla lekarzy jakich specjalności specjalizacja ta jest dostępna. Tu znajdujemy pierwszy wyłom w logicznym jak do tej pory łańcuchu szkoleń i kompetencji. Otóż umiejętność ta zarezerwowana jest dla specjalistów z zakresu Medycyny Morskiej i Tropikalnej (którzy potrzebną wiedzę zdobyli $\mathrm{w}$ trakcie szkolenia specjalizacyjnego), Medycyny Transportu i Lotniczej, którzy również $\mathrm{w}$ większości zdobyli wiedzę podczas szklenia specjalizacyjnego, Medycyny Ratunkowej i Toksykologii co jest uzasadnione w szczególności do ostrych zatruć tlenkiem węgla. Trudno jest natomiast logicznie wytłumaczyć dwie pozostałe specjalizacje wymienione $\mathrm{w}$ załączniku. Są to: Medycyna Pracy i Anestezjologia i Intensywna Terapia.

Obecność tych dwóch specjalizacji dla których hiperbaria nie ma jakiegokolwiek zastosowania byłoby wytłumaczalne, gdyby istniała możliwość podjęcia szkolenia i uzyskania umiejętności przez lekarzy innych specjalności: ortopedów, chirurgów czy diabetologów. Jednak rozporządzenie takiej możliwości nie stwarza.

Niestety nie jest to jedyny i najistotniejszy rozdźwięk pomiędzy spójnymi i logicznymi programami specjalizacji lekarskich a obowiązującymi rozporządzeniami ministerialnymi.

Największym problemem dla normalnego i zgodnego z logiką rozwoju medycyny hiperbarycznej w Polsce jest Obwieszczenie Ministra Zdrowia z 14 kwietnia 2016 (D.U. 2016 poz. 694) [9] i wszystkie akty therapy of diseases in other fields of medicine ... within practical skills - 11) knowledge of the principles of hyperbaric therapy for other medical specialisations.

Based on the specialisation training programme, this medical specialisation should be considered as having all the predispositions to conduct hyperbaric treatment.

Particularly noteworthy is the specialisation in the field of Anaesthesiology. While in the previously applicable one-stage specialisation programme in the chapter devoted to intensive therapy, section "Toxicology" [7] we find subsection 4 - Hyperbaric therapy, and in current specialisation programme Anaesthesiology and Intensive Therapy (modular) there is no mention of hyperbaric treatment. Presumably the head of the Experts' Team creating the specialisation program, Professor Krzysztof Kusza came to the right conclusion that hyperbaric therapy is not applicable in anaesthesia or intensive therapy, thus these issues have not been included in the programme [5].

However, since there are not many experts in Poland in Marine and Tropical Medicine, similarly to Transport or Aviation Medicine, the best solution for the qualifications problem would be a Medical Skill. It would allow specialists in fields where hyperbaric therapy is used: for example, surgeons or otolaryngologists, to acquire the knowledge needed to safely use this method of therapy. And indeed, such a skill is on the list of "skills in the narrower fields of medicine" [8].

Appendix 1 to this regulation constitutes a list of skills, with Hyperbaric Medicine found in item 30 . Appendix 2, on the other hand, specifies the type of physicians for whom this specialisation is available. Here we find the first gap in the thus far logical chain of training and competences. Namely, this skill is reserved for professionals in the area of Maritime and Tropical Medicine (who gained the required knowledge during specialisation training), Transport and Aviation Medicine (who also mostly gained knowledge during specialisation training), Emergency Medicine and Toxicology, which is justified in particular for cases of acute poisoning with carbon monoxide. It is however difficult to present a logical explanation to two other specialisations listed in the Appendix. These are: Occupational Medicine, Anaesthesiology and Intensive Therapy.

The presence of these two specialisations, where hyperbaric oxygenation has no application whatsoever, would be explainable if it was possible to take up training and obtain the skills via doctors of other specialisations: orthopaedists, surgeons and diabetologists. However, the regulation does not create such an opportunity.

Unfortunately, this is neither the only nor the most important discrepancy between coherent and logical programmes of medical specialisation and applicable ministerial regulations.

The biggest problem preventing the development of hyperbaric medicine in Poland from taking a normal direction and being consistent with a given logic, is the announcement of the Minister of Health on 14 April 2016 (JL. 2016 it. 694) [9] and all acts prior to this document containing mentions of hyperbaric therapy. We read there, inter alia: the following specialists are entitled to pursue hyperbaric treatment: in the field of anaesthesiology or anaesthesiology and resuscitation, or anaesthesiology and intensive care therapy, or emergency medicine and clinical toxicology, having completed a course of hyperbaric medicine in accordance with the recommendations of the European Committee for 
prawne poprzedzające niniejszy dokument a zawierające wzmianki o terapii hiperbarycznej. Czytamy tam między innymi: do prowadzenia terapii hiperbarycznej uprawnieni sq specjaliści: $w$ dziedzinie anestezjologii lub anestezjologii $i$ reanimacji, lub anestezjologii i intensywnej terapii, lub medycyny ratunkowej, lub toksykologii klinicznej, posiadający ukończony kurs medycyny hiperbarycznej zgodnie z zaleceniami Europejskiego Komitetu Medycyny Hiperbarycznej.

Jak widać $\mathrm{z}$ powyższego tekstu, obwieszczenie powstało $\mathrm{w}$ całkowitym oderwaniu od obowiązującego w Rzeczypospolitej Polskiej systemu kształcenia podyplomowego lekarzy. Nie uwzględnia ono ani specjalizacji dających kwalifikacje do prowadzenia terapii hiperbarycznej ani specjalizacji w których ten rodzaj terapii jest stosowany.

Odwołuje się natomiast do zaleceń instytucji zagranicznej bez wzmianki o konieczności dostosowań tych zapisów do istniejących w Polsce unormowań prawnych.

Zalecenia o których mowa w obwieszczeniu Ministra Zdrowia zawarte są w Europejskim kodeksie dobrej praktyki $w$ leczeniu tlenem hiperbarycznym $\mathrm{z}$ roku 2004 [10]. W Aneksie 1 tego dokumentu znajdujemy Standardy kształcenia i szkolenia praktycznego dla personelu Ośrodków Medycyny Hiperbarycznej. Kwalifikacje lekarzy ujęte są w sposób następujący: ... lekarzem medycyny posiadajacym szerokie wielospecjalistyczne wyszkolenie. Najlepsze wykształcenie moga zapewnić: medycyna chorób wewnętrznych, intensywna opieka i/lub intensywna terapia, reanimacja $i$ anestezjologia. Inne specjalności również moga być odpowiednie, jeśli kandydat ma udokumentowane doświadczenie oraz otrzymał niezbędne wykształcenie $i$ wyszkolenie praktyczne $w$ zakresie Medycyny Hiperbarycznej.

Ze względu na mniejszą liczbę specjalizacji w innych krajach Europy logicznym jest uwzględnienie na pierwszym miejscu chorób wewnętrznych (np. cukrzyca stopa cukrzycowa), natomiast wymogom „niezbędnego wykształcenia i wyszkolenia” w polskim systemie specjalizacji odpowiada Medycyna Morska i Tropikalna, bądź też dowolna inna specjalizacja po uzyskaniu umiejętności Medycyna Hiperbaryczna. Jednak w obwieszczeniu znalazła się niestety anestezjologia.

$\mathrm{Na}$ uwagę zasługuje także część dokumentu, definiująca i stopniująca kwalifikacje lekarzy. Stopnie I i IIa to wedle Europejskiego Komitetu:

I. Lekarze - orzecznicy kwalifikujący nurków do wykonywania zawodu. Sprzeczność z obowiązującym w Polsce prawem jest oczywista, gdyż regulujące kwestie orzecznicze w odniesieniu do nurków Rozporządzenie Ministra Zdrowia [11] w żadnym punkcie nie odwołuje się do dokumentu Europejskiego Komitetu i proponowanego tam systemu szkolenia, ale przede wszystkim logicznie koresponduje $\mathrm{z}$ systemem specjalizacji medycznych, wyznaczając do orzekania specjalistów medycyny morskiej i tropikalnej, medycyny transportu, medycyny lotniczej oraz przeszkolonych dodatkowo specjalistów medycyny pracy. Czyli osoby kompetentne w danej dziedzinie.

IIa. Lekarze „medycyny nurkowej” - znów uprawnienia orzecznicze oraz dodatkowo, wejście w kompetencje specjalistów medycyny sądowej poprzez postępowanie w zakresie wypadków nurkowych

Dopiero kwalifikacje oznaczone IIb - lekarz medycyny hiperbarycznej związane są $\mathrm{z}$ leczeniem hiperbarią tlenową.

\section{Hyperbaric Medicine.}

As can be seen from the above text, the announcement was created in complete isolation from the system of postgraduate education of physicians used in the Republic of Poland. It does not include specialisations that qualify physicians to conduct hyperbaric therapy or specialisations in which this type of therapy is used.

However, it refers to the recommendations of a foreign institution without mentioning the need to adapt these provisions to existing legal regulations in Poland.

The recommendations referred to in the Announcement of the Minister of Health are included in the European Code of Good Practice in hyperbaric oxygen treatment from 2004 [10]. In Annex 1 of this document we find the Standards of education and practical training for the personnel of Hyperbaric Medicine Centres. The qualifications of doctors are specified as follows: ... a medical doctor with a broad multi-specialised training. The best education can be provided by: internal medicine, intensive care and/or intensive therapy, reanimation and anaesthesiology. Other specialisations may also be appropriate if the candidate has documented experience and has received the necessary education and practical training in the field of Hyperbaric Medicine.

Due to the smaller number of specialisations in other European countries, it is logical to position internal diseases in to first place (e.g. diabetes - diabetic foot), while the requirements of "necessary education and training" in the Polish system of specialisation are met by Maritime and Tropical Medicine, or any other specialisation after obtaining the skills of Hyperbaric Medicine. Unfortunately, however, the announcement suggests anaesthesiology.

Noteworthy is also the part of the document that defines and classifies doctors' qualifications. Stages I and IIa according to the European Committee are as follows:

I. Physicians - doctors certifying divers to practice. The inconsistency with Polish law is obvious, since nowhere in the regulations of the Minister of Health concerning the issues related to diver qualification [11] does it refer to the European Committee document, and the training system proposed there, but most of all, they logically correspond with the system of medical specialisations, by appointing specialists in marine and tropical medicine, transport medicine, aviation medicine and additionally trained occupational medicine specialists to take qualification decisions. Therefore, people competent in a given field.

IIa. "Diving medicine" doctors - with qualification authority, and, additionally, having the competences of forensic specialists in the proceedings related to diving accidents.

Only qualifications marked IIb - hyperbaric medicine doctor - are connected with hyperbaric oxygen treatment.

Obtaining this "title" is contingent upon completion of the course, whose programme can also be found in the currently discussed document. The important positives include the following requirement: it is highly recommended that the courses are taught by a university; it is highly advisable to conduct them by national authorities in the field of health protection, under the auspices of the national scientific society of diving medicine and/or hyperbaric medicine. Unfortunately, it is not fully implemented in the majority of courses organised in Poland.

In the analysis of the course programme, it 
Uzyskanie tego „tytułu” warunkowane jest ukończeniem kursu, którego program znajduje się również $\mathrm{w}$ omawianym aktualnie dokumencie. Do istotnych pozytywów należy zaliczyć wymaganie: jest bardzo zalecane, aby kursy były prowadzone przez wyższa uczelnię; bardzo wskazane jest ich prowadzenie przez krajowe autorytety $w$ dziedzinie ochrony zdrowia, pod auspicjami krajowego towarzystwa naukowego medycyny nurkowej i/lub medycyny hiperbarycznej. Niestety, nie jest ono w większości kursów organizowanych w Polsce w pełni realizowane.

Analizując program kursu należy w pierwszym rzędzie stwierdzić, że zakres wiedzy zdobywanej podczas szkolenia specjalizacyjnego w specjalności „Medycyna Morska i Tropikalna" zawiera większość tematów objętych szkoleniem, co potwierdza bezzasadność przenoszenia in extenso zapisów Kodeksu ECHM na polski grunt prawny. Wskazuje na to także analiza zawartości merytorycznej kursu. Otóż jest to przede wszystkim kurs medycyny nurkowej, obejmującej w dużym zakresie wiadomości nie mające zastosowania przy klinicznym leczeniu hiperbarią tlenową. Procentową zawartość tematyczną kursu przedstawia rys. 1. should first be confirmed that the scope of knowledge acquired during the specialisation training within "Maritime and Tropical Medicine" contains the majority of topics covered by the training, which confirms the unjustifiability of transfer of the provisions of the ECHM Code onto Polish legal ground. This is also indicated by the analysis of the substantive content of the course. Namely, it is primarily a diving medicine course that largely covers the information that does not apply to clinical treatment with hyperbaric oxygen. The percentage distribution of the thematic content of the course is shown in Figure 1.

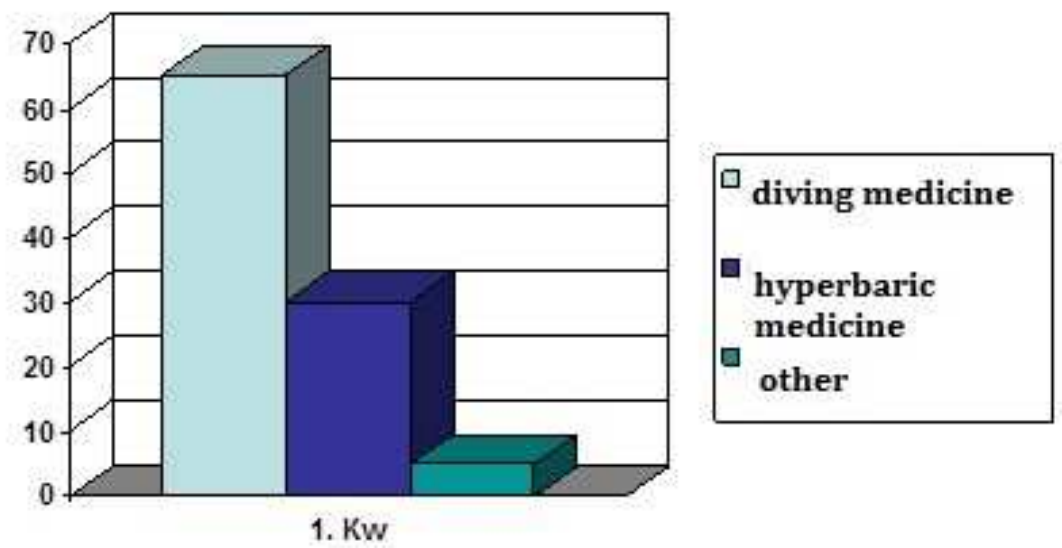

Fig. 1 The ECHM course programme.

Rys. 1 Program kursu ECHM.

Rzetelnie prowadzony wedle programu zawartego w dokumencie Europejskiego Komitetu kurs musi trwać około 2 tygodni i angażować grupę kilkunastu specjalistów jako wykładowców. Mając świadomość, iż ponad połowa materiału wykładowego nie ma dla uczestników szkolenia żadnego znaczenia praktycznego, należałoby zastanowić się nad dostosowaniem programu szkolenia do zasad prawnych panujących w Polsce, co przyniosłoby pozytywny efekt zarówno edukacyjny jak i ekonomiczny.

Należy także stwierdzić, że istniejący w Polsce system szkolenia podyplomowego pozwala na szybki, odpowiadający trendom Europy i Świata rozwój terapii hiperbarycznej. Dokonanie poprawek w dwóch jedynie dokumentach sygnowanych przez Ministerstwo Zdrowia: Obwieszczeniu w sprawie świadczeń gwarantowanych i Rozporządzeniu w sprawie umiejętności rozwiązałoby większość problemów z kadrą lekarską, z jakimi borykają się ośrodki hiperbaryczne, dodatkowo nasilanych przez niedobór specjalistów - anestezjologów w Polsce.

Wymagania co do personelu medycznego opisane w Obwieszczeniu dotyczą, jak sam tytuł obwieszczenia wskazuje, jedynie świadczeń gwarantowanych, czyli refundowanych przez Państwo.
The programme conducted in concord with the instructions included in the European Committee document, dictates that the course must last about 2 weeks and involve a group of over a dozen specialists as lecturers. Being aware of the fact that over half of the lecture material is of no practical significance to the participants, programme adjustment should be considered to the legal principles effective in Poland, which would bring a positive educational and economic effect.

It should also be stated that the system of postgraduate training existing in Poland allows for the rapid development of hyperbaric therapy, corresponding to the trends prevailing in Europe and the world. Making corrections only in two documents signed by the Ministry of Health: The Announcement on guaranteed services and the Regulation on medical skills would solve most problems concerning the medical personnel in hyperbaric centres, additionally escalated by the shortage of specialists - anaesthesiologists in Poland.

The requirements for medical personnel described in the Announcement relate, as the title itself indicates, only to guaranteed services, i.e. those reimbursed by the State. However, in Poland, there are 
Natomiast w Polsce jak grzyby po deszczu powstają coraz liczniejsze ośrodki oferujące możliwość przebywania pod podwyższonym ciśnieniem tlenu, nie wiążące się umową z Narodowym Funduszem Zdrowia. Są to instytucje prywatne, dysponujące różnymi rodzajami obiektów hiperbarycznych (jednomiejscowe, wielomiejscowe) o różnych zakresach ciśnień pracy i deklarujące bardzo szeroką gamę usług. Ośrodki te, oferują zarówno leczenie hiperbaryczne chorób według zaleceń współczesnej wiedzy medycznej, jak i innych, dla których oksybaroterapia nie jest wskazaniem, bądź badania nie potwierdzają jej skuteczności. Coraz częściej tlen hiperbaryczny stosowany jest także jako wspomaganie treningu sportowego i w kosmetyce, gdzie reklamowany jest jako „sposób odmładzania”.

Jedyną wspólną cechą wszystkich tych instytucji jest brak obowiązujących norm prawnych, które nakładałyby na nie obowiązek posiadania wyszkolonego personelu. Oczywiście liczne ośrodki, szczególnie te, które dysponują komorami wielomiejscowymi i oferują zakres leczenia taki sam, jak ośrodki finansowane $\mathrm{z}$ budżetu państwa zatrudniają personel posiadający odpowiednie kwalifikacje i duże doświadczenie. Niestety, w większości przypadków, szczególnie w odniesieniu do komór jednomiejscowych, tzw. „miękkich”, nie sa one zabezpieczane przez lekarzy posiadających odpowiedni zasób wiedzy.

Dlatego istnieje pilna potrzeba określenia wymagań co do kwalifikacji personelu lekarskiego również dla ośrodków prywatnych, najlepiej przez wymagalność umiejętności medycznej "Medycyna Hiperbaryczna", bądź certyfikowanego kursu i ujęcia tego w Rozporządzeniu Ministra Zdrowia more and more centres offering the possibility of undergoing hyperbaric oxygen therapy not bound by an agreement with the National Health Fund. These are private institutions that have different types of hyperbaric facilities (single-seat, multi-seat) with different working pressure ranges and declaring a very wide range of services. Such centres offer both hyperbaric treatment of diseases in accordance with the recommendations of modern medical knowledge, as well as other conditions for which oxybarotherapy is not an indication, or its effectiveness is not confirmed by research. Hyperbaric oxygen is also more often used as a support therapy in sports and cosmetics, where it is advertised as a "rejuvenation method".

One common feature of all these institutions is the lack of binding legal norms that would impose the obligation of hiring trained personnel. Of course, many centres, especially those with multi-seat chambers offering the same treatment range as centres financed from the state budget, employ staff with appropriate qualifications and extensive experience. Unfortunately, in most cases, particularly when it comes to single-seat, socalled "soft" chambers, protection is not ensured by doctors possessing suitable knowledge.

Therefore, there is an urgent need to determine the requirements for the qualifications of medical personnel also in private centres, preferably by requiring the medical skills of medical specialisation of Hyperbaric Medicine, or a certified course, and including this in the Regulation of the Minister of Health.

\title{
REFERENCES
}

Sieroń A., Cieślar G. (ed.) An Outline on Hyperbaric Medicine. a-medica press Bielsko - Biała 2006 ISBN 83-88778-97-8;

Doboszyński T., Orłowski T. (ed.) The Basics of Hyperbaric Oxygenation. Wydawnictwo Wojskowej Akademii Medycznej Gdynia 1977;

Kindwall E., Goldmann R. (ed.) Hyperbaric Medicine Procedures. St. Lukes Medical Center Milwakuee WI USA 1995;

Weaver L. (ed.) Hyperbaric Oxygen Therapy Indications. Undersea and Hyperbaric Medical Society Best Publishing Company North Palm Beach, FL USA 2014 ISBN 978-1930536-73-9;

5. http://www.cmkp.edu.pl/ksztalcenie/studia-specjalizacyjne-lekarzy/programy-specjalizacji-lekarskich/modulowe-programy-specjalizacji. Downloaded: 2017-12-02;

6. http://www.cmkp.edu.pl/ksztalcenie/studia-specjalizacyjne-lekarzy/programy-specjalizacji-lekarskich/archiwum-programow/archiwumspecjalnosci-szczegoowe. Downloaded: 2017-12-02;

7. http://www.cmkp.edu.pl/ksztalcenie/studia-specjalizacyjne-lekarzy/programy-specjalizacji-lekarskich/archiwum-programow/archiwumspecjalnosci-podstawowe/. Downloaded: 2017-12-02;

8. Minister of Health Regulation of 27 June 2007. JL. of 11 July 2007, 124.867;

9. Announcement of the Ministry of Health of 14 April 2016 on publication of the consolidated text of the Minister of Health Regulation on guaranteed hospital treatment services. JL. of 26 May 2016, 2016 694.490;

10. http://www.echm.org/documents/ECGP\%20for\%20HBO\%20-\%20May\%202004\%20-\%20PL.pdf Downloaded: 2017-12-02;

11. Minister of Health Regulation of 11 February 2011 amending the regulation on health conditions applied in the performance of underwater works. JL. 2011.40211 .2776

\author{
dr hab. med. Piotr Siermontowski \\ Zakład Technologii Prac Podwodnych \\ Akademia Marynarki Wojennej \\ 81-127 Gdynia, ul. Śmidowicza 69 \\ naczelny@phr.net.pl
}

